\title{
The Development of the Fibreboard Doctrine: The Duty To Bargain Over Economically Motivated Subcontracting Decisions
}

The Supreme Court's recent decision in Fibreboard Paper Products Corp. v. $N L R B^{1}$ upheld a finding by the National Labor Relations Board that an employer had violated section $8(a)(5)^{2}$ of the National Labor Relations Act by failing to negotiate with the bargaining representative of its maintenance crew before subcontracting the maintenance work previously handled by that crew. ${ }^{3}$ At the close of its discussion of the duty to bargain, the Court, attempting to restrict its holding to the facts of the case, held that even though the employer's decision was purely an economic one devoid of anti-union animus,

the type of "contracting out" involved in this case-the replacement of employees in the existing bargaining unit with those of an independent contractor to do the same work under similar conditions of employment-is a statutory subject of collective bargaining under $\$ 8(d){ }^{4}$

The Court also affirmed the Board's remedy in Fibreboard, an order directing the employer to reinstate the discharged employees with back pay, resume its own maintenance operations, and bargain with the union before again deciding to subcontract. 5

1379 U.S. 203 (1964).

2 The following are the pertinent parts of $\S 8(a)$ :

It shall be an unfair labor practice for an employer-

(1) to interfere with, restrain, or coerce employees in the exercise of the rights guaranteed in Sec. 7 of this title; ... .

(3) by discrimination in regard to hire or tenure of employment or any term or condition of employment to encourage or discourage membership in any labor organization ...

(5) to refuse to bargain collectively with the representatives of his employees . National Labor Relations Act $\S 8(a)(1),(3),(5), 61$ Stat. 136 (1947), 29 Uं.S.C. \$ $158(\mathrm{a})(1)$, (3), (5) (1964).

3 The employer had long handled its maintenance work through its own employees, who had been represented by a local of the Steelworkers Union since 1937. In 1959, the employer determined that it could save substantially by "contracting out" its maintenance work. It did so by eliminating the entire maintenance unit without bargaining with the union. Under the "contracting out" system used, the contractor provided the maintenance workers, but the employer provided the supplies and remained in control of most of the operation.

4879 U.S. at 215.

5 For extensive discussion of the Fibreboard case, see 14 Catrolic U.L. REv. 247 
The significance of this decision is that prior to Fibreboard the NLRB had not required employers to bargain before making purely economically motivated subcontracting decisions. "Refusal to bargain" charges filed under section $8(a)(5)$ had generally been joined with charges involving anti-union activities filed under sections $8(a)(1)$ or 8 (a) (3). Proof of anti-union motivation had been required for the finding of a refusal-to-bargain violation, ${ }^{7}$ and economically motivated decisions could be made unilaterally by the employer; he was bound only to bargain over the effects of the decision. ${ }^{8}$

The Board's decision in Fibreboard ${ }^{9}$ thus represents the first NLRB thrust into the rather ill-defined area of "subcontracting,"10 an area of

(1965). See also Forkosch, Bargaining and Economic Pressure-The New Trilogy, 16 LAB. L.J. 323 (1965); Summers, Labor Law in the Supreme Court: 1964 Term, 75 YALE L.J. 59 (1965); Comment, The Scope of Collective Bargaining, 74 YALE L.J. 1472 (1965); 60 Nw. U.L. REv. 558 (1965). That these writers seem to arrive at different interpretations of Fibreboard is an interesting commentary on the lack of clarity of the Court's opinion.

6 To the Board, Town \& Country Mfg. Co., 136 N.L.R.B. 1022, 49 L.R.R.M. 1918 (1962), may have marked the establishment of this requirement of the duty to bargain before making economically motivated decisions. But anti-union motives were involved in that case so the Board had to wait for a case like Fibreboard to make clear its new viewpoint.

7 See, e.g., National Gas Co., 99 N.L.R.B. 273, 30 L.R.R.M. 1065 (1952); Krantz Wire \& Mfg. Co., 97 N.L.R.B. 971, 29 L.R.R.M. 1191 (1952); Celanese Corp. of America, 95 N.L.R.B. 664, 28 L.R.R.M. 1362 (1951); Walter Holm \& Co., 87 N.L.R.B. 1169, 25 L.R.R.M. 1270 (1949); Hays Corp., 64 N.L.R.B. 406, 17 L.R.R.M. 114 (1945); Mahoning Mining Co., 61 N.L.R.B. 792, I6 L.R.R.M. 110 (1945). The only case which can be considered an exception to this pattern is Timken Roller Bearing Co., 70 N.L.R.B. 500, 18 L.R.R.M. 1370 (1946), where the Board found the employer's failure to bargain concerning an "Employees' Manual" to be a violation. However, this manual directly affected union activities-one rule in the manual prohibited the distribution of literature-and thus could be considered part of anti-union activities. A second refusal-to-bargain violation concerning a dispute which had gone to arbitration involved such a morass of issues that the rationale behind the Board's finding is difficult to discern. It appears doubtful in any event that the Board considered this decision a break with its traditional doctrine since it was not until some fifteen years later, when the Board was in need of "precedent," that this inconclusive and confusing decision took on an authoritative quality. Renton News Record, 136 N.L.R.B. 1294, 49 L.R.R.M. 1972 (1962) and Town \& Country Mfg. Co., 136 N.L.R.B. 1022, 49 L.R.R.M. 1918 (1962), decided several months before Fibreboard, represent the germination of the Fibreboard doctrine. In both cases the Board declared that an employer could be forced to bargain over an economically motivated decision, but since Town \& Country involved anti-union bias, and Renton News entailed an order to bargain only over the effects of the decision, these statements must be considered dicta. See notes 43-49 infra and accompanying text.

8 See, e.g., Shamrock Dairy, Inc., 119 N.L.R.B. 998, 41 L.R.R.M. 1216 (1957) (tenure of the employees); Brown Truck \& Trailer Mfg. Co., 106 N.L.R.B. 999, 32 L.R.R.M. 1580 (1953) (future placement of the employees); Brown-McLaren Mfg. Co., 34 N.L.R.B. 984, 9 L.R.R.M. 50 (1941) (transfer of employees to a new plant). For a thorough summary of the pre-Fibreboard law in this area, see Comment, Employer's Duty To Bargain About Subcontracting and Other "Management" Decisions, 64 Colum. L. REv. 294 (1964).

9138 N.L.R.B. 550, 51 L.R.R.M. 1101 (1962).

10 Crawford, The Arbitration of Disputes Over Subcontracting, mimeographed article on 
decision-making previously recognized as properly within the unilateral discretion of the employer. ${ }^{11}$ The future impact of this thrust lies in the Board's approach to its expanded power. This comment attempts to discern such an approach through an examination of the Board's post-Fibreboard decisions, to identify the criteria which the Board is applying to economically motivated decisions, and to suggest some desirable refinements and improvements in the Board's approach.

The Board has chosen to deal with the problem of the employer's duty to bargain over subcontracting decisions on a case-by-case approach. Rather than find a violation of the duty to bargain every time an employer makes a unilateral decision to subcontract, the Board has adopted a more flexible system adaptable, at least in theory, to the facts of each individual case. ${ }^{12}$

\section{The Threshold Concept of "Detriment"}

In making its case-by-case determinations, the Board has not always been clear as to what criteria it is using to differentiate those economically motivated unilateral decisions which constitute unfair labor

file in the Review office, suggests the wide range of possible meanings which can be given the terms "subcontracting" or "contracting out" and describes the institutional structure from which the cases discussed in this comment arose.

11 The subject of the extension of the duty to bargain and the ensuing invasion of managerial prerogatives is quite controversial. The Fibreboard extension of this duty has brought some strong, if perhaps less than objective, reactions. See, e.g., Anderson, Plant Removals and Subcontracting of Work, 15 LAB. L.J. 609 (1964); 60 Nw. U.L. REv. 558 (1965).

For a more general and analytical argument against the extension of the duty to bargain, see Independenr Study Group, The Public Interest in National Labor Policy (1961); Cox, The Duty to Bargain in Good Faith, 71 Harv. L. Rev. 1401 (1958); Cox \& Dunlop, Regulation of Collective Bargaining by the National Labor Relations Board, 63 Harv. L. Rev. 389 (1950). But see Ross, The Government as a Source of Union Power (1965); Findling \& Colby, Regulation of Collective Bargaining by the National Labor Relations Board-Another View, 51 Colum. L. REv. 170 (1951).

12 In Shell Oil Co., 149 N.L.R.B. No. 26, 57 L.R.R.M 1279 (Oct. 29, 1964), the Board stated:

The principles of [Fibreboard $]$... are not meant to be hard and fast rules to be mechanically applied irrespective of the circumstances of the case. In applying these principles, we are mindful that the permissibility of unilateral subcontracting will be determined by a consideration of the setting of each case. Id., 57

L.R.R.M. at 1280 .

Similar statements appear in Central Soya Co., 151 N.L.R.B. No. 161, 58 L.R.R.M. 1667 (April 14, 1965); Allied Chem. Corp., 151 N.L.R.B. No. 76, 58 L.R.R.M. 1480 (March 16, 1965); Superior Couch Corp, 151 N.L.R.B. No. 24, 58 L.R.R.M. I369 (Feb. 19, 1965); Westinghouse Elec. Corp. (Mansfield), 150 N.L.R.B. No. 136, 58 L.R.R.M. 1257 (Feb. 5, 1965). But see Summers, supra note 5, at 60-63, suggesting that the Court's opinion in Fibreboard projected "a workable standard for determining what subjects fall within the reach of mandatory bargaining" which standard renders at least some forms of subcontracting mandatory subjects of bargaining. 
practices from those which do not. Nevertheless, it has settled on a threshold requirement, satisfaction of which is necessary, though not always sufficient, to establish that the economically motivated unilateral decision violated section $8(a)(5)$. This threshold concept, which may be characterized as "detriment," requires that the unilateral decision have caused substantial harm to the members of the bargaining unit. Detriment to employees appears to be a logical criterion for the Board to use in exempting decisions from the duty to bargain. Because negotiating a decision is generally more costly than making a decision unilaterally, it would not make sense to force the employer to negotiate unless harm to the employees could thereby be averted. ${ }^{13}$

Although there is good reason for using a detriment concept, defining detriment presents some complicated problems, which the Board has not yet been able to resolve. In Westinghouse Electric Corp. (Mansfield), ${ }^{14}$ the Board approached a comprehensive definition by endeavoring to reconcile prior Board findings of section $8(a)(5)$ violations. It maintained that in those cases in which the Board had found a refusal to bargain:

$[\mathrm{I}] \mathrm{t}$ has invariably appeared that the contracting out . . . effected a change in conditions of employment, or resulted in a significant impairment of job tenure, employment security or reasonably anticipated work opportunities for those in the bargaining unit. ${ }^{15}$

On its face, the general statement is of little predictive value. But it does include two ideas which have recurred in the Board's later decisions: a violation of section $8(a)$ (5) results from subcontracting which changes employment conditions or impairs reasonably anticipated work opportunities. The former criterion appears to be the more valuable of the two in that it serves to explain the Board's decisions in a clearer and more consistent manner. "Reasonable anticipation" is not only a difficult test to apply, but also fails to explain a number of the Board's decisions.

"Reasonable anticipation" does not explain, for example, cases in which the union argued that "significant detriment" existed when the

13 See page 324 infra.

14150 N.L.R.B. No. 136, 58 L.R.R.M. 1257 (Feb. 5, 1965). The employer in this case had a long established pattern of subcontracting. In the period covered by the complaint, the employer had let out over seven thousand contracts, many of which were within the capabilities of his work force. He did not notify or consult with the union in connection with any of the contracting out. Basing its decision on the lack of detriment and on the established pattern of contracting out, the Board dismissed the complaint.

15 Id., 58 L.R.R.M. at 1258. 
subcontracting caused the failure to return certain workers with craft classification, who previously had been demoted to production for lack of craft work, to their old positions. ${ }^{16}$ Representative of the Board's response to that argument is American Oil Co. (Neodesha), ${ }^{17}$ in which it held that the refusal to bargain over the subcontracting was not a section $8(a)(5)$ violation because there was "no real change in terms and conditions of employment of the employees in the bargaining unit."18 If a "reasonable anticipation" test had been applied to such a situation, the decision might have been different. Since the workers' demotions from craft work were temporary, with reinstatement to occur upon increased plant need for craft work, it would not seem unreasonable for these employees to have anticipated promotion when such need arose. Subcontracting the new work would, of course, frustrate this expectation; hence, the "reasonable anticipation" test fails to explain these Board decisions. However, the "change" test does justify the result since the subcontracting did not adversely affect the existing positions of the workers; they were craft workers doing production work before as well as after the managerial decision. The only change involved was the original demotion, which was not the result of the managerial decision in question.

Westinghouse Electric Corp. (Bettis) ${ }^{19}$ illustrates another shortcoming of the "reasonable anticipation" test. There the Board spoke in terms of "reasonable anticipation" in establishing a lack of detriment. In that case the union argued that the employer's unilateral decision to subcontract had caused "significant detriment" in the form of loss to laid-off workers of potential opportunities for being rehired. The Board rejected this argument since the layoffs had occurred two years before the managerial decision and there was no showing that any workers were still eligible for or interested in being rehired. The Board stated:

In the circumstances, it is our opinion that lost work opportunities which rest upon so remote a chain of possibilities as is present in this record cannot in fairness be characterized as "reasonably anticipated."20

16 American Oil Co. (Neodesha), I52 N.L.R.B. No. 7, 59 L.R.R.M. 1007 (April 22, 1965); Central Soya Co., 151 N.L.R.B. No. 161, 58 L.R.R.M. 1667 (April 14, 1965); American Oil Co. (Whitney), 151 N.L.R.B. No. 45, 58 L.R.R.M. 1412 (March 3, 1965); Westinghouse Elec. Corp. (Mansfield), 150 N.L.R.B. No. 136, 58 L.R.R.M. 1257 (Feb. 5, 1965).

17152 N.L.R.B. No. 7, 59 L.R.R.M. 1007 (April 22, 1965). Also see other cases cited note 16 supra.

18 Ibid.

19153 N.L.R.B. No. 33, 59 L.R.R.M. 1355 (June 24, 1965).

20 Id., 59 L.R.R.M. at 1857. 
But, as Chairman McCulloch noted in dissent, the employees had a contractual right to be recalled to work and sixty-five employees were still eligible for this right. McCulloch's conclusion that the "laid-off unit employees suffered a 'significant detriment' in that they were deprived of a 'reasonably anticipated' right to be recalled to perform the subcontracted work"21 indicates that the "reasonable anticipation" test is likely to be difficult to apply because Board members and judges are likely to disagree as to what employees actually anticipated and as to whether those anticipations were reasonable. On the other hand, the "change" test is much less likely to yield disagreement and on the Westinghouse (Bettis) facts could only have produced the result ultimately arrived at by the Board. The subcontracting did not cause the layoff of the workers, who were laid off several years before the decision to subcontract. As in American Oil, the unilateral decision did not change the existing work status of the employees.

Three factors favor the "change" test. First, it explains all of the Board's detriment decisions and may explain the actual thought processes of the Board. Second, it is easier to apply than a "reasonable anticipation" test since the Board does not have to analyze the workers' mental deliberations or even those of an abstract "reasonable" worker, but can make its determinations on more easily ascertainable criteria such as whether the managerial decision itself caused a change in the working arrangements of the firm, such as layoffs, demotions, or reduced hours. Third, the clarity of the test gives the employer some certainty as to the legality of his unilateral decision. It does not require him to predict such "potential" harm to the employee as loss of promotion or of overtime, both of which might still be within the "reasonable" anticipations of his employees. The employer knows what the general conditions of employment are and whether his decision will involve actual-not potential-layoffs, or reduction in hours, work loads, or status. If it does call for such actual changes, he knows that he must bargain over the decision. If it does not, he can safely make the decision unilaterally. It would appear that the "change" test provides the ease of application and predictability which are called for in a threshold concept of detriment. Since the "reasonable anticipation" test lacks these attributes and fails to explain many of the Board's past decisions, it would appear wise for the Board to discontinue using it. ${ }^{22}$

21 Id., 59 L.R.R.M. at 1359.

22 There may be situations in which the consistent use of a "reasonable anticipation" test would give results more equitable to the employee in that it would reflect actual harm caused by the subcontracting but not recognized by the "change" test. Taking an example from the difficult area of "overtime," seasonal fluctuations may be so predictable that 


\section{Factors Justifying Failure to Bargain}

Although the Board has not fully delineated the concept of detriment, it seems clear from the decisions that the term will be strictly construed to exclude a large class of economically motivated decisions from section $8(a)(5)$ liability. ${ }^{23}$ But even if the threshold requirement of detriment has been met, the propriety of the employer's unilateral decision is open to further scrutiny by the Board. At this point the Board has not adopted a uniform approach although a number of factors that avowedly influence its decisions can be identified.

One such factor is the history of past negotiations. Inspection of the cases indicates, however, that the "past negotiations" factor is of little importance in the Board's determinations. In most of the cases in which the concept is mentioned, it is less a means of arriving at a decision than a makeweight advanced to support a decision reached on other grounds. ${ }^{24}$ The situations in which the Board apparently has

employees come to rely on overtime at certain times in the year. It is doubtful that the "change" test would recognize the loss of such overtime through subcontracting as sufficient detriment, whereas a "reasonable anticipation" test might. However, when applying a threshold test in the hope of weeding out certain cases early in the administrative process, a simpler and more predictable test is desirable, especially when it is capable of identifying a great part of the harm sought to be remedied. Also of practical importance is the fact that the Board indicates it would not apply the "reasonable anticipation" test to require bargaining over subcontracting which only affects potential overtime. See General Tube Co., 15I N.L.R.B. No. 89, 58 L.R.R.M. 1496 (March 19, 1965). As has been seen, the Board tends to limit its use of cases in which a finding of detriment is dictated by the "change" test. Thus, the Board's use of the "reasonable anticipation" test serves only to create confusion without even obtaining the benefit of giving employees additional protection.

In terms of actual Board results, it is interesting to note that findings of detriment have consistently been accompanied by actual loss of jobs. However, unlike "change," "loss of jobs" has been explicitly rejected as a test. American Oil Co. (Whitney), 151 N.L.R.B. No. 45, 58 L.R.R.M. 1412 (March 3, 1965). "Loss of jobs" would appear to be an unnecessarily restrictive criterion, even from the standpoint of employer certainty. It is only slightly more difficult for the employer to determine whether his decision will directly result in reduced hours than to determine whether jobs will be lost. But see Comment, Subcontracting, Mandatory Collective Bargaining, and the 1965 NLRB Decisions, 18 STAN. L. REv. 256, 258 (1965).

23 In strictly construing the threshold concept of detriment, the Board has inhibited the bringing of "expansion" cases; in such cases there is no harm to the employees in the bargaining unit, but the union, fearing that the employer's decision to subcontract work rather than hire new employees denies a potential source of expansion in size and perhaps in power, brings $\S 8(a)(5)$ charges even though the subcontracting causes no harm-potential or actual-to the present workers. Although the Supreme Court's decision in Fibreboard was broad enough to give the unions hope of obtaining such leverage, in Allied Chemical Co., 151 N.L.R.B. No. 76, 58 L.R.R.M. 1480 (March 16, 1965), a typical case of this sort, the Board dismissed the complaint, finding that such a claim "is no showing of any detriment, let alone significant detriment." Id., 58 L.R.R.M. at 1481. See also Fafnir Bearing Co., 151 N.L.R.B. No. 40, 58 L.R.R.M. 1397 (Marrh 1. 19k5).

24 See cases cited note 30 infra. 
considered past negotiations to be independently determinative-the "waiver" situations-are few in number and will probably diminish in the future. ${ }^{25}$

The Board has many times discussed past negotiations in dealing with the employer's defense that he had already satisfied his duty to bargain prior to the unilateral decision. In this connection, it is interesting to compare Adams Dairy, Inc. ${ }^{26}$ with cases like Westinghouse Electric (Mansfield). ${ }^{27}$ Adams Dairy involved the assignment of milk delivery routes, previously handled by employee delivery men, to independent driver-salesmen and the ensuing loss of jobs. The trial examiner, whose report was adopted by the Board, noted that in negotiations on three occasions the union had unsuccessfully attempted to secure a contract provision restricting the company's freedom to sell through independent driver-salesmen. He ruled, however, that this did not constitute prior fulfillment of the employer's duty to bargain over the decision in question since the subject matter involved was different. ${ }^{28}$ In Westinghouse (Mansfield) the Board noted, in deciding for the employer, that "the union on three separate occasions sought contract language limiting the established subcontracting practice." 29 There seem to be no rational grounds for distinguishing between the importance of the bargaining opportunities in these two cases. Yet in Westinghouse (Mansfield) the Board said the prior opportunity to bargain operated in the employer's favor while in Adams Dairy it did not. It would appear that the real distinction involved is not related to the bargaining opportunities themselves. In Adams Dairy, significant detriment existed in the loss of a number of jobs as a direct result of the employer's decision, while in Westinghouse (Mansfield), as noted earlier, the Board found that there was no significant detriment. Indeed, in all the cases in which prior opportunity to bargain was used to support the conclusion that the employer fulfilled his obligations, lack of detriment had already decided the issue..$^{30}$ The Board, if concerned with the

25 See notes $32-37$ infra and accompanying text.

26137 N.L.R.B. 815, 50 L.R.R.M. 1281 (1962).

27150 N.L.R.B. No. 136, 58 L.R.R.M. 1257 (Feb. 5, 1965).

28 The trial examiner maintained the union's aim in the prior negotiations was to protect the employee drivers against losing part of their income, while total job loss was involved in the employer's unilateral decision. The distinction between "all" and "part" is not persuasive since the practice which caused either of the losses and which the union was attempting to restrict-contracting out to independent driver-salesmenwas the same.

29150 N.L.R.B. No. 136, 58 L.R.R.M. 1257, 1258 (Feb. 5, 1965).

30 See, e.g., American Oil Co. (Neodosha), 152 N.L.R.B. No. 7, 59 L.R.R.M. 1007 (April 22, 1965); Allied Chem. Corp., 151 N.L.R.B. No. 76, 58 L.R.R.M. 1480 (March 16, 1965); Fafnir Bearing Co., 151 N.L.R.B. No. 40, 58 L.R.R.M. 1397 (Feb. 19, 1965); 
precedential value of cases recognizing the "opportunity to bargain" defense to a section $8(a)(5)$ charge, can easily distinguish those cases by relying on the changes in circumstance which usually will occur between the old negotiations and the unilateral decision. ${ }^{31}$

A narrower aspect of past negotiations which is considered by the Board to have determinative value is a union's contractual "waiver" of its right to bargain. However, while the Board will consider "waiver" a determinative factor, it does so only when a union has waived its statutory right to bargain by express language or when there is at least a strong inference that the union intended to waive the right by general language. ${ }^{32}$

The Board has also applied a restrictive approach to "management prerogative" clauses, the form in which employers would most often argue that a union has waived its bargaining right. In Fafnir Bearing Co. ${ }^{33}$ the Board upheld the trial examiner's dismissal of the union's complaint but refused to adopt his conclusion that the general management rights clause in the contract precluded unilateral subcontracting. ${ }^{84}$ On the other hand, Shell Oil Co. ${ }^{35}$ and General Motors Co., ${ }^{36}$ cases cited by the Board in Fafnir, involved management rights clauses which the Board held waived the union's right to bargain over the specific decision in question. But those clauses specifically referred to the unilateral decision in question, subcontracting. Thus the presumption against waiver appears quite strong: absent contractual clauses which deal explicitly with the particular type of decision involved, the Board will not find that the union has waived its bargaining rights. The number

Westinghouse Elec. Corp. (Mansfield), 150 N.L.R.B. No. 136, 58 L.R.R.M. 1257 (Feb. $5,1965)$.

31 The trial examiner in Adams Dairy used such a technique.

32 "A waiver of a statutory right is not to be lightly inferred but must be "clear and unmistakable." " New York Mirror, 151 N.L.R.B. No. 110, 58 L.R.R.M. 1465, 1467 (March 19, 1965). In Puerto Rico Tel. Co., 149 N.L.R.B. No. 84, 57 L.R.R.M. 1397 (Nov. 30, 1964), the Board also noted that failure to assert the statutory right to bargain does not waive the union's right to assert it later.

33151 N.L.R.B. No. 40, 58 L.R.R.M. 1397 (March I, 1965).

34 Id., 58 L.R.R.M. at 1398. See Trial Examiner's Report, I-CA-4175, 4361, 4477, TXD-660-64. The clause read: "The management of the company and the direction of the work force, including but not limited to, the right to hire, . . . the right to determine the extent to which the plants shall be operated including ... the right to change methods or processes or to use new equipment, is reserved exclusively in the company, except as specifically abridged or modified by this agreement." Trial Examiner's Report at 7.

The trial examiner concluded that "the Board has held that similar . . . clauses ... establish the employer's 'managerial prerogative' unilaterally . . . to subcontract unit work without transgressing the bargaining requirements of the Act . . ." Id. at 11 .

35149 N.L.R.B. No. 26, 57 L.R.R.M. 1279 (Oct. 29, 1964).

36149 N.L.R.B. No. 49, 57 L.R.R.M. 1277 (Oct. 30, 1964). 
of cases in which such clauses appear may become even smaller in the future, for the collective bargaining contracts with such clauses which have thus far come before the Board were negotiated before the Supreme Court's decision in Fibreboard. In those cases the unions' acquiescence in the "waiver" clause may in part be explained by their feeling that they were not giving up substantial rights, since before Fibreboard it was generally assumed that management had the right to make unilateral decisions on subcontracting. Since Fibreboard, however, unions have been aware of the potential restrictions on unilateral employer action and may be less likely to make "waiver" concessions. ${ }^{37}$

Even after excluding those unilateral managerial decisions which are not of "significant detriment" or over which the union has specifically waived its bargaining rights, it is clear that the Board still feels that neither all unilateral managerial decisions nor all "contracting out" managerial decisions are equally amenable to negotiation. Although the cases suggest that the Board has not consciously adopted a consistent set of criteria in determining which managerial decisions are amenable to negotiation, the decisions are explainable by two factors: the likelihood of beneficial or effective negotiation and the costs of negotiation. Some managerial decisions in which there is less likelihood that the union could suggest a viable alternative to the decision are more properly left to management than others. Also, their urgency or necessity renders the delaying of some decisions by the collective negotiation process prohibitively costly. "Good faith" bargaining could require the employer to remain at the bargaining table long enough to force the loss of an important opportunity to make a profit or avert a loss. Under such circumstances, the costs of negotiation to the employer, and through him to the economy, may perhaps be quite high. The greater the likelihood that the union can offer a viable alternative to the unilateral decision, the higher the cost in terms of a duty to bargain which the Board should be willing to impose on the employer.

Cases like New York Mirror ${ }^{38}$ show that the Board is not completely unaware of these considerations. There Hearst, the employer, sold the Mirror's name, assets, and good will to the New York Daily News. After the sale, approximately 1,300 employees and their unions were informed that their employment would be terminated. No employee knew of

37 The general lack of clarity in the area of "waiver" makes such predictions difficult. Fibreboard will probably create such a tendency on the part of unions; the effect of that tendency on the number of "waivers" depends on such elusive factors as the institutional structure of the bargaining arrangements, the relative aggressiveness of the particular union, and the Board's own complex "waiver" policy.

38151 N.L.R.B. No. 110, 58 L.R.R.M. 1465 (March 19, 1965). 
the employer's plans to sell until after the sale had taken place since the employer had not negotiated with the unions concerning the decision to terminate activities. ${ }^{39}$ The unions, relying on Fibreboard, filed charges alleging the employer's refusal to bargain. Although the "detriment" question in this case was somewhat complicated, large scale job loss did occur, and no argument appears to have been made that "significant detriment" had not occurred.40 "Waiver" was argued by the employer and rejected by the Board. ${ }^{41}$ Thus the employer had made a unilateral decision which caused significant detriment to his employees and was not absolved from a duty to bargain by any contractual waiver. Yet the Board dismissed the refusal-to-bargain charge.

Although the Board did not make clear the reason for its decision, it apparently decided that mitigating circumstances were present. ${ }^{42}$ These involved the economic necessity of the employer's decision and the union's apparent lack of desire to seek the restoration of the employer's operations and the employees' jobs. The Board made no attempt to explain the interrelation of the circumstances or how they led to its decision, but it would appear that the Board's reaction was based on a feeling that everything possible had been done; consequently, the employer's decision was largely "inevitable" and no amount of negotiation could have altered it.

30 The Board assumed it had the right to consider "termination of activities" decisions by employers under the Fibreboard rubric. However, "termination of activities" may no longer be within the Board's Fibreboard power. Textile Workers Union v. Darlington Mfg. Co., 380 U.S. 263 (1965), held the complete closing of one's business to be an absolute managerial prerogative and qualified that prerogative in the case of a partial closing only if effective anti-union activities were present. Although Darlington did not deal directly with a $\$ 8(a)(5)$ violation, the circuit courts have relied on it in denying enforcement of Board orders involving $\S 8(\mathrm{a})(5)$ findings against employers on the ground that the economically motivated decision concerned "termination of business activities." NLRB v. Royal Plating \& Polishing Co., 350 F.2d 191, 196 (3d Cir. 1965); NLRB v. Adams Dairy, Inc., 350 F.2d 108, 112-13 (8th Cir. 1965), petition for cert. filed, 34 U.S.L. TWEEK 3219 (U.S. Dec. 7, 1965) (No. 804); NLRB v. Burns Int'l Detective Agency, 346 F.2d 897, 902 (8th Cir. 1965).

40 The employer established an employment service for his ex-employees and apparently placed a number of them in other jobs. However, since 1300 people remained out of work for varying amounts of time, the unilateral decision did result in a "change in conditions."

41 See note 32 supra and accompanying text.

42 One group of circumstances appears to relate to the good faith and cooperative attitude of the employer, involving his fulfillment of the duty to bargain over the effects of his decisions. Although he did an excellent job of attempting to mitigate the effects of his decision to sell the business, the union charged him with violating his duty to bargain over the decision itself. While the Board may have viewed the employer with favor because it thought he acted admirably toward his employees after making his decision, this factor does not explain why he had no duty to bargain before the decision. See note 46 infra. 
The first factor mentioned by the Board was that the "decision ... was prompted solely by pressing economic necessity." 43 In connection with this observation, the Board cited Renton News Record, ${ }^{44}$ which involved the failure of an employer to bargain over the installation of automating devices. Detriment was present because jobs were eliminated, and the Board found the employer guilty of an unfair labor practice. However, despite the finding against the employer, the sole remedy was an order to bargain over the effects of the decision as opposed to the standard remedy of back pay, reinstatement, and an order to bargain over the decision itself. 45 Thus, the Board in Renton News in effect absolved the employer from its duty to bargain about the decision. ${ }^{46}$ The Board relied primarily upon the fact that the employer was "faced with the choice of either changing [its] ... method of operations to one at least equal to that of [its] . . competitors or being forced to go out of business." 47 The Board had somehow narrowed the employer's alternatives to two, neither of which would have solved the employees' dilemma. It viewed the employer's decision or at least the detrimental loss of jobs as inevitable. Thus the reference to Renton News in the New York Mirror decision, in the context of the Board's observation about "pressing economic necessity," may have reflected the view that here too the alternatives were limited and that none would have saved the employees' jobs. Reinforcing this inference is the Board's observation that the union was not even proposing the restoration of jobs. ${ }^{48}$ That the employers in both Renton News and New York Mirror were newspaper publishers may also shed some light upon the Board's approach. It is common knowledge that metropolitan daily newspapers have been diminishing in number and that in general their economic

43 151 N.L.R.B. No. 110, 58 L.R.R.M. at 1468.

44136 N.L.R.B. 1294, 49 L.R.R.M. 1972 (1962).

45 The Board in Renton News assumed, apparently solely on the basis of dicta in Town \&: Country Mfg. Co., 136 N.L.R.B. 1022, 1029-30, 49 L.R.R.M. 1918, $1921-22$ (1962), that this would "ordinarily" be the proper remedy for an economically motivated refusal to bargain. See text accompanying note 5 supra.

46 The finding against the employer and the remedy order are no doubt explained by the failure of the Renton employer to negotiate over effects. The finding of no duty to bargain over the decision itself is identical to the New York Mirror result and supports the suggestion made in note 42 supra, that the cooperative stance of the employer in negotiating the effects had little to do with the propriety of refusing to bargain over the decision itself. In Renton the employer had been less cooperative than the employer in Mirror; both were excused.

47136 N.L.R.B. 1294, 1297-98, 49 L.R.R.M. 1972, 1974 (1962).

48 The remedy sought was back pay from the date of the newspaper's closing to the date each employee found substantially equivalent employment. 
position has not been very stable.49 This factor may have made the Board more sympathetic to the difficulties confronting the employer.

In situations like those in New York Mirror and Renton News, it is very likely that had negotiations taken place the resulting decision would have been identical with the unilateral one. It appears that the inevitability of the employer's decision, or the probable impotency of negotiations, had an important bearing on the Board's decisions in these two newspaper cases..$^{50}$ However, it also appears that the NLRB is reluctant to recognize this concept expressly and has purported to reject it as an independent consideration. Thus the Board asserted in New York Mirror:

The elimination of unit work is no less within that statutory phrase ["other terms and conditions of employment"] when it is to result from a management decision affecting an entire operation. And this is so even though the likelihood is slim that prior consultation with the union will alter the employer's contemplated decision. ${ }^{51}$

However, an examination of the case demonstrates that this statement is inconsistent with the decision itself. ${ }^{52}$ It is suggested that the con-

49 The complex and varied factors causing change in this industry range from technological innovation in printing to changes in the rate structure of advertising. These factors have established a definite pattern of merger or cessation among newspapers. See Newspapers Fight a Dollar Deadline, Bus. Week, Sept. 11, 1965, p. 136. This information was available to the Board in the trial examiner's report which stated: "This instant case should, I believe, be considered in relation to the modern history of the newspaper industry, particularly in the City of New York, and that history is one of sale, merger, and discontinuance." Trial Examiner's Report, 2-CA-9619, etc., TXD-166-64, at 10. The trial examiner continued with an extensive discussion of the economic state of the newspaper industry.

50 Another possible example of the Board's implicit use of this concept occurred in Ador Corp., 150 N.L.R.B. No. 161, 58 L.R.R.M. 1280 (Feb. 10, 1965). The employer founded the corporation in 1956 and sold it in 1959. When the new owners proved unable to keep the business solvent the original owner was appointed referee of the bankruptcy proceedings. He was authorized by the court to serve as general manager of Ador and in that capacity decided to eliminate a line of products which he felt had caused the insolvency of the company. Eliminating the product caused the loss of several jobs. The Board found for the employer on the basis of an extensive managerial rights clause in the collective bargaining agreement. However, the Board could have declined to find a waiver because of the expiration of the contract before the termination of the jobs and the general language of the clause. See notes 32-34 supra and accompanying text. It would appear that the entrepreneurial ability of the employer and the financial straits of the company may well have been the determining factors. As in Renton News and New York Mirror, the Board may have been moved by the fact that negotiations would have served no purpose since the employer's decision was the only practical alternative.

51151 N.L.R.B. No. 110, 58 L.R.R.M. at 1466. (Emphasis added.)

62 The Board's own analysis of its Renton decision in a later case shows that such con- 
siderations which have been shown to underlie the Board's decision in New York Mirror and Renton News are highly relevant to the determination of the duty to bargain in all cases of economically motivated decisions. The usefulness and cost of negotiation varies from case to case, and the Board should be willing to hear employer arguments that because of these two general factors his decision to bypass negotiation was a "reasonable" one.

In dealing with this employer argument, the Board might profitably adopt a presumption in favor of negotiations. In terms of the analysis presented earlier, the Board might presume that negotiation would be fruitful and inexpensive. There are two reasons for creating such a presumption. The first is clarity and ease of administration. The Board's task would be simplified if the presumption in favor of negotiations could be overcome only by a clear showing-perhaps beyond reasonable doubt-that negotiations would have been fruitless and costly. A strong presumption would discourage employers from consuming the Board's time with marginal arguments. A second reason for the presumption is the "psychic" benefit of negotiations; even negotiations which will not alter the decision may have the desirable effect of giving the employee a feeling of having participated in making decisions which vitally concern him. Although such a consideration should not be carried too far, it underscores the desirability of reluctance in abandoning negotiations. Having raised this presumption, the Board should make clear the conditions under which it is rebuttable. The process exhibited in New York Mirror of disclaiming the argument on the one hand while allowing it to determine the decision sub rosa is both confusing and unfair. There are several sources of proof based upon information usually available to the Board which the employer could use in making his argument. He might rebut the presumption of the usefulness of negotiations with evidence of the ineffectiveness of past negotiations with the union; $;^{53}$ he would be allowed to show that the union's help

siderations were present. In differentiating the facts in Royal Plating \& Polishing Co., 148 N.L.R.B. No. 59, 57 L.R.R.M. 1006 (Aug. 27, 1964), from those in Renton News, the Board stated: "The Board is not here confronted with a situation where an immediate termination of Respondent's business became a matter of pressing economic necessity. Here no change in technology ... had made the continuance of the Respondent's business prohibitively costly .... Nor can we say that, had the Respondent made a good faith effort to acquaint the union with the contemplated sale of its property and of its business difficulties, it would not have brought forth an offer from the union which could have produced desired economies and permitted the Respondent to continue its business if not at its old location, then at another." Id., 57 L.R.R.M. at 1008.

53 This, as has been seen, is information which is readily available to the Board and which it has utilized in the past. See text accompanying notes 24-31 supra. One com- 
had previously been sought on the problem involved and that the union had failed to help, either from lack of ability or unwillingness to cooperate. ${ }^{54} \mathrm{~A}$ second source of rebuttal evidence would be the practices of competitors, which could support the employer's claim that his decision was part of an established industry pattern and that failure to make the change would have resulted in great competitive disadvantage. ${ }^{55}$ Other factors which should be relevant to the Board's determination of the potential value of bargaining might include a substantial decrease in demand for the employer's product, ${ }^{56}$ natural catastrophe, and change in governmental policy, all of which might greatly reduce the number of alternatives open to the employer. To rebut the presumption of low cost of negotiations, he should be permitted to prove that particular opportunities might have been lost with the passage of time in negotiation. ${ }^{57}$

If the presumption favoring negotiation is overcome by a showing that the potential value of negotiations was low in relation to their cost, the NLRB should find that failure to negotiate the decision was not an unfair labor practice.

mentator recently suggested that the duty to bargain should be imposed if the decision affects employees' vital interests and if the considerations motivating the decision are generally the subject of collective bargaining. Comment, The Scope of Collective Bargaining, 74 YALE L.J. 1472, 1477-78 (1965). This test could serve as a substitute for the test based on the union's ability to help the employer suggested here. But its use would only provide a partial analysis since it does not consider such external factors as industrywide economic problems (New York Mirror) or the need to take advantage of technological advances (Renton News). Moreover, as applied by the commentator, it does not even serve this partial analytical role, but merely renames the problem, suggesting that some decisions are managerial, but providing little but intuition as the determining factor. Id. at 1478.

54 The Board has taken note of such considerations in other contexts. For example, in Shell Oil Co., 149 N.L.R.B. No. 26, 57 L.R.R.M. 1279, 1280 (Oct. 26, 1964), the Board stated: "At this meeting as at the earlier one, the Union offered no specific proposals but simply voiced its objections to the transfer."

55 This argument found favor with the Board in Renton News. See notes $43-47$ supra and accompanying text. The fact that the change in question is one which the industry in general has adopted is a strong indication of the absence of feasible alternatives.

50 This factor was present in $A d o r$. See note 50 supra.

57 Any argument presented by the employer should be subject to refutation by the union. Aside from attempts to refute the particular factual assertions of the employer, the union might wish to offer proof of its competency in this area. For example, if an International Ladies' Garment Workers' Union (ILGWU) local is involved, it would seek to point out that it had at its disposal, through the national union, technical engineers or loan funds to aid the employer. See Forkosch, Bargaining and Economic PressureThe New Trilogy, 16 LAB. L.J. 323, 329 n.25 (1965); cf. Spun-Jee Corp., 152 N.L.R.B. No. 96, 59 L.R.R.M. 1206 (May 26, 1965). The union might also refute the employer's contentions concerning the usefulness of negotiations by presenting workable alternatives which it would have offered if it had been given the opportunity. 


\section{Summary}

In its post-Fibreboard decisions, the NLRB has established "detriment" as a threshold concept and has given some determinative weight to the narrowly defined concept of "waiver." Beyond these limited concepts, however, the Board has failed to adopt a discernible, consistent framework of analysis in assessing an employer's duty to bargain over economically motivated decisions. The Board has, however, implicitly utilized a number of analytical considerations. The framework suggested here is but one attempt to make these considerations explicit, thereby consistently incorporating them into a workable approach to Fibreboard-type problems and providing a basis upon which both management and labor can better predict the Board's actions. 